\title{
Статус и обряд - новая выставка Института археологии и этнографии о клинковом оружии в археологии и этнографии народов Сибири
}

\author{
Дарья Гаркуша \\ Институт археологии и этнографии СО РАН, \\ Новосибирск, Россия
}

В феврале - марте 2021 г. в Институте археологии и этнографии Сибирского отделения РАН работала выставка «Статус и обряд: клинковое оружие у народов Сибири». Под руководством научных кураторов, ведущих научных сотрудников института, д-ра ист. наук А. П. Бородовского и д-ра ист. наук А. В. Бауло, выставка рассказывает посетителям о том, что с глубокой древности и до этнографического времени клинковое оружие в Сибири имело не только непосредственное боевое назначение, но и подчеркивало статус владельца и использовалось в обрядовых практиках.

В качестве экспонатов были представлены археологические находки и предметы из этнографических сборов сотрудников института, раскрывающие особенности использования холодного оружия народами Сибири в различные исторические эпохи (рис. 1-3). Демонстрировались экспонаты из Музея истории и культуры народов Сибири и Дальнего Востока ИАЭТ СО РАН и Музея Природы и Человека (город Ханты-Мансийск). Сейчас для просмотра доступен подробный виртуальный тур по выставке, подготовленный совместно с компанией Novosibpano.

Географический и хронологический охват выставки внушителен: представлены предметы от Забайкалья до нижнего течения Оби. Наиболее старинные экспонаты имеют возраст три с половиной тысячи лет, самые поздние датируются началом XX в.

Выставка условно поделена на две части - археологическую и этнографическую. В первой части особое значение, по мнению А.П. Бородовского, имеет бронзовый меч, обнаруженный около города Байкальска (рис. 4). Этот массивный меч при изготовлении распался на три части и, тем не менее, в составном виде сохранил своё ритуальное значение. Гарда оформлена в виде двух медвежьих голов, меж- 




Puc. 1. Общий вид экспозиции в Центре коллективного пользования «Геохронология кайнозоя» ИАЭТ. Фото С.А. Борисенко

Fig. 1. General view of the exhibition in the Cenosic Geohronology Centre of Collective Usage of the Institute of the Archaeology and Ethnography SB RAS. Photo by S.A. Borisenko

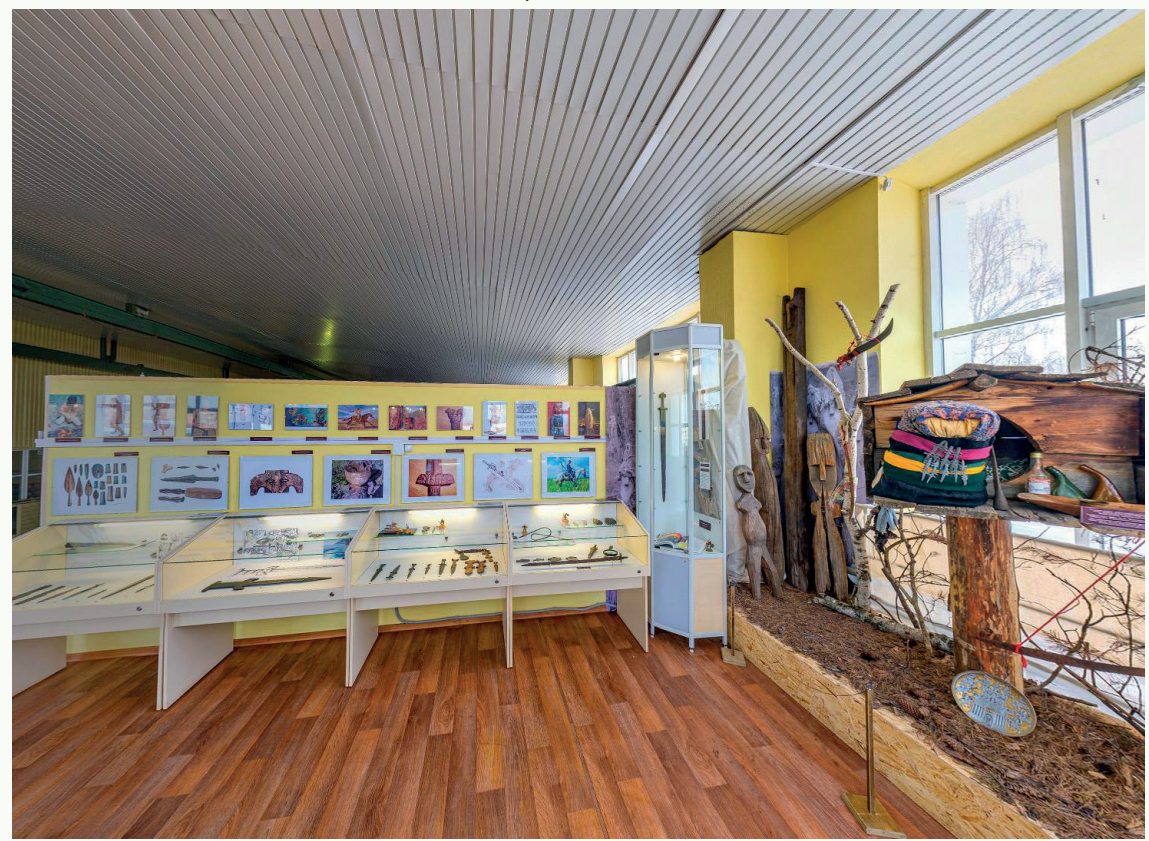

Puc. 2. Археологическая часть выставки. Общий вид. Фото С.А. Борисенко Fig. 2. Archaeological part of the exhibition. Photo by S.A. Borisenko 


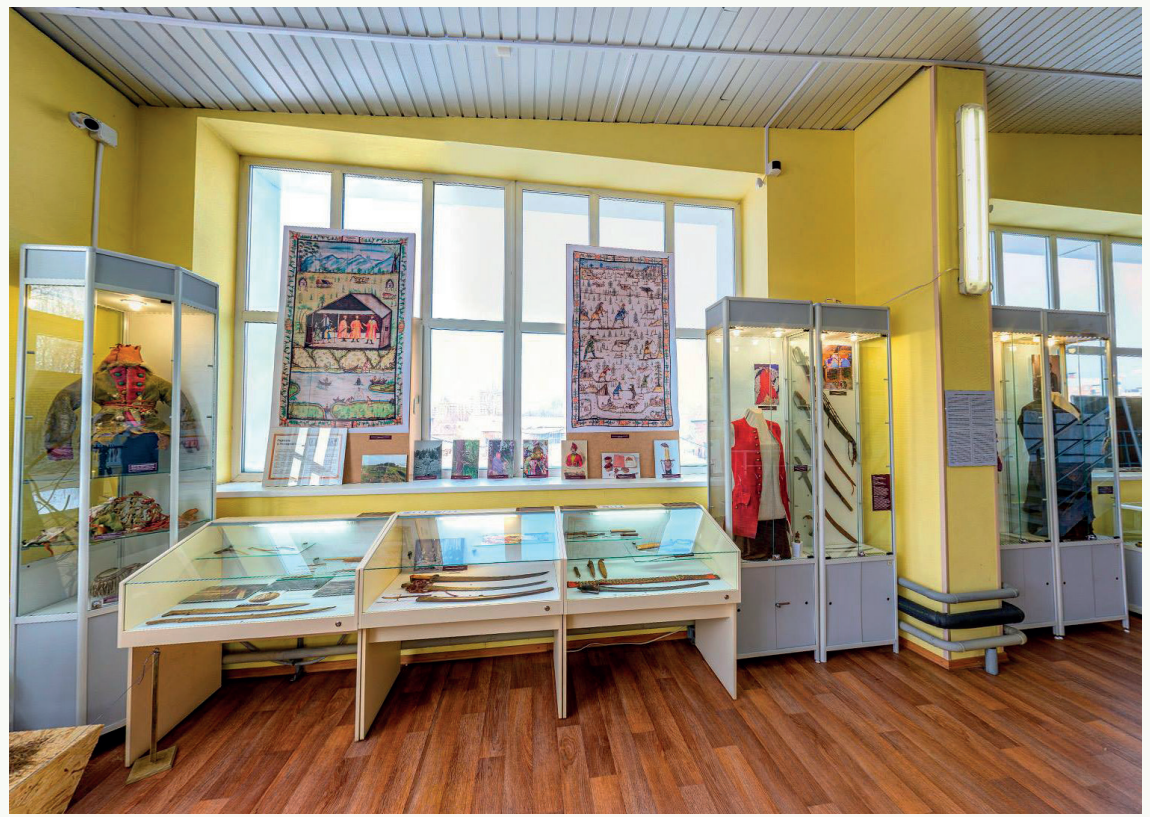

Puc. 3. Этнографическая часть выставки. Общий вид. Фото С.А. Борисенко Fig. 3. Ethnographic part of the exhibition. Photo by S.A. Borisenko

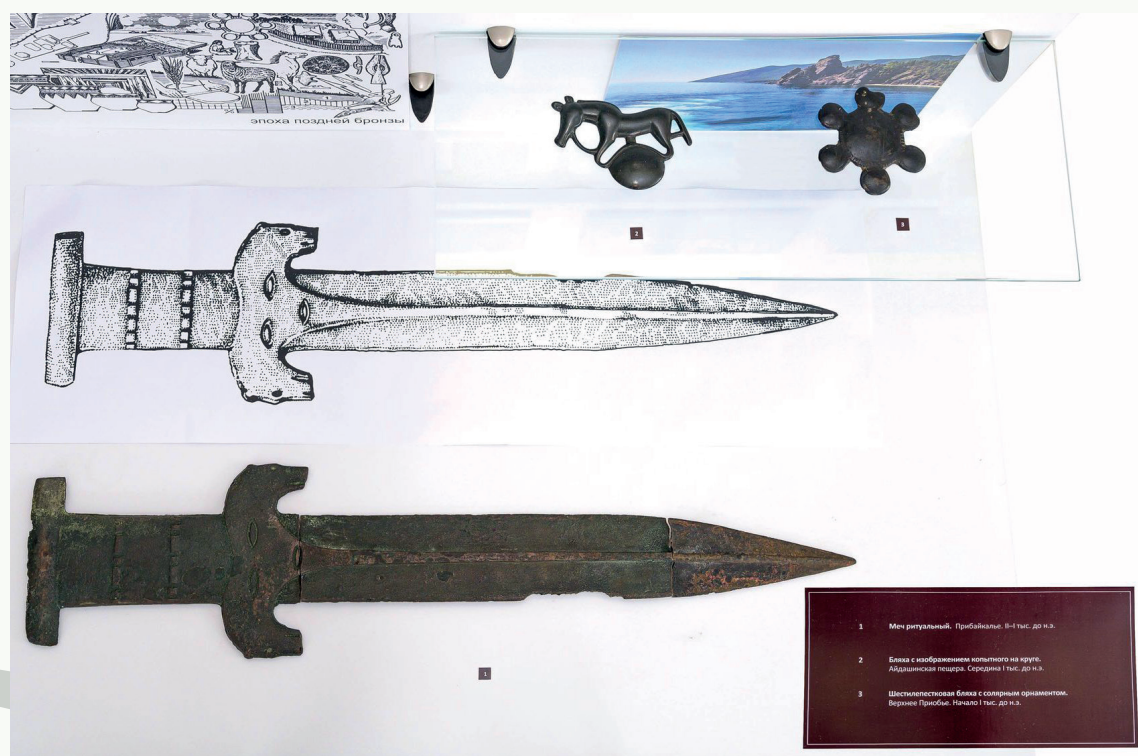

Puc. 4. Бронзовый меч из Байкальска. Фото С.А. Борисенко

Fig. 4. Copper sword found not far from Baikal. Photo by S.A. Borisenko 




Puc. 5. Железный палаш с надписью на согдийском языке. Фото С.А. Борисенко

Fig. 5. Iron broadsword with Sogdian inscription. Photo by S.A. Borisenko

ду которыми помещена личина - такое оформление может говорить о принадлежности меча шаману. Подробнее об этой интересной находке можно прочесть в публикации В.И. Молодина и Г.И. Медведева «Уникальный бронзовый меч из Прибайкалья» (2015).

Среди других редких экспонатов - железный палаш с инкрустированной золотом надписью на согдийском языке (рис. 5-6). Палаш был найден в погребении IX в. в Кош-Агачском районе Горного Алтая. Хотя само оружие могло быть местного происхождения, надпись на нём сделана не на древнетюркском, а на согдийском языке. Она гласит «Это собственность П.., сына Н... И ему (=владельцу меча) вреда да не будет». Буквы в именах повреждены, поэтому прочесть их невозможно. Подробнее об этом предмете можно узнать в статье автора находки, доктора исторических наук В.Д. Кубарева «Палаш с согдийской надписью из древнетюркского погребения на Алтае» (1992).

Большое внимание аудитории привлёк и меч Каролингов, находка которого при раскопках в Барабе, в 120 километрах от Новосибирска, вызывает удивление до сих пор (рис. 7-8). Автор находки, заведую-

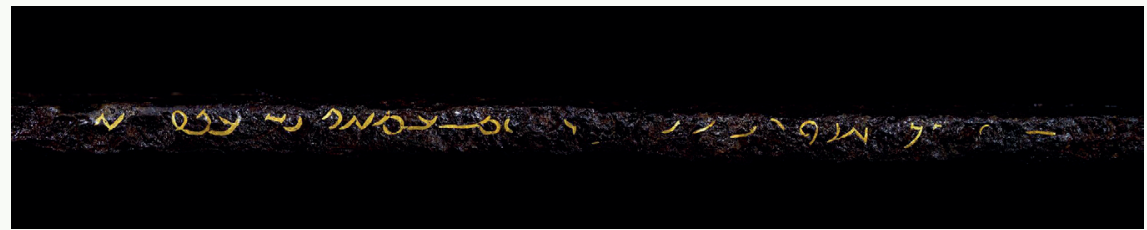

Puc. 6. Железный палаш с надписью на согдийском языке. Фрагмент. Фото С.А. Борисенко

Fig. 6. Iron broadsword with Sogdian inscription. A fragment. Photo by S.A. Borisenko 



Puc. 7. Меч Каролингов, обнаруженный в Барабе. Фрагмент. Фото С.А. Борисенко

Fig. 7. Carolingian sword found in the Baraba steepe. A fragment.

Photo by S.A. Borisenko 


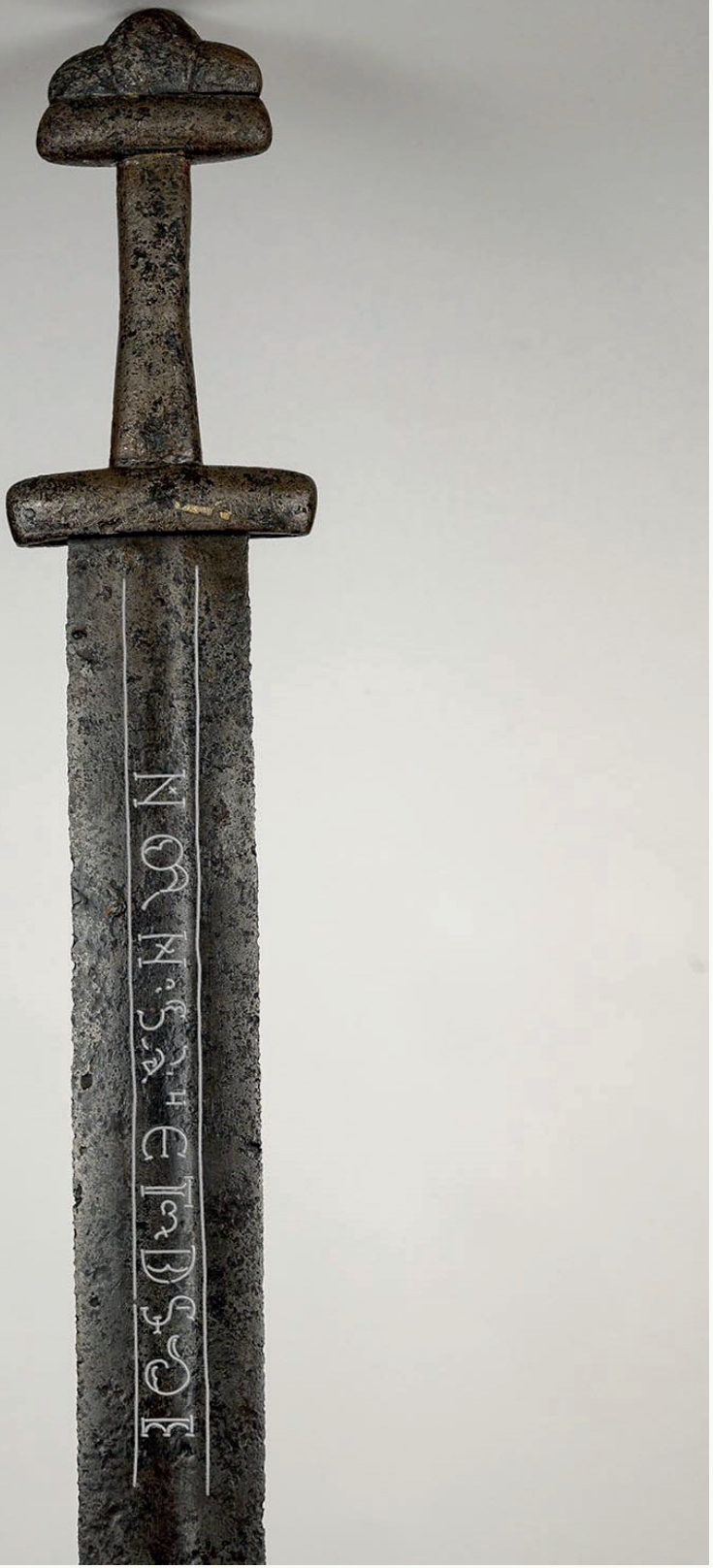

Puc. 8. Меч Каролингов, обнаруженный в Барабе. Фрагмент с наложенной прорисовкой надписи. Фото С.А. Борисеко

Fig. 8. Carolingian sword found in the Baraba steepe. A fragment with a drawing of the inscription. Photo by S.A. Borisenko 


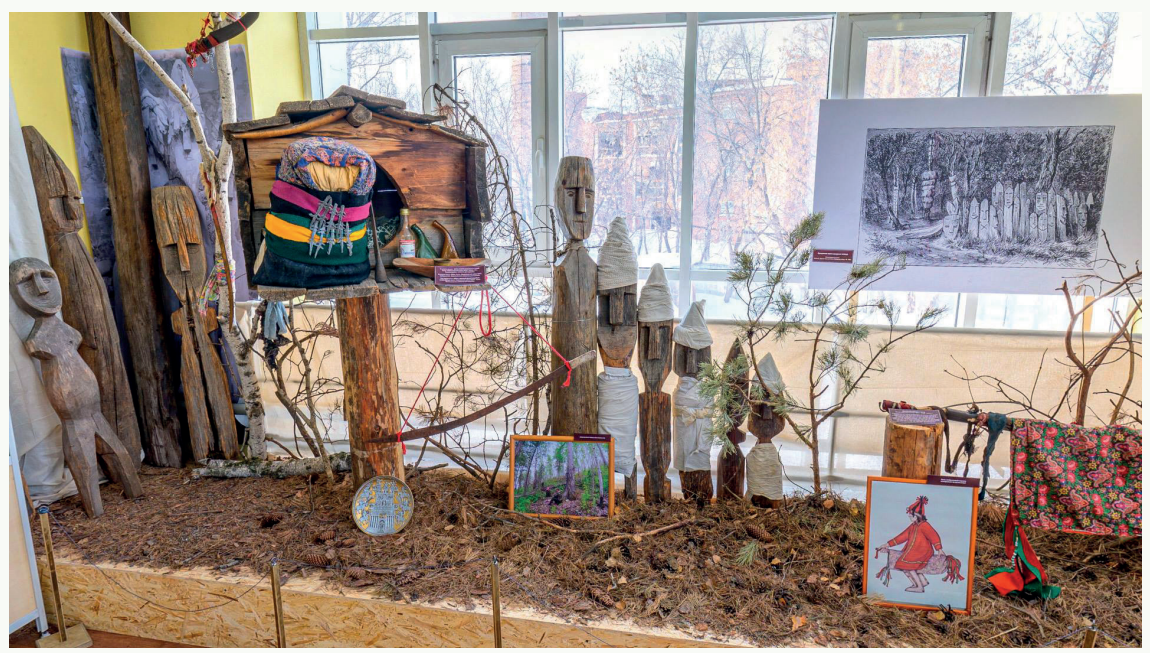

Puc. 9. Мансийское святилище с амбарчиком. Фото С.А. Борисеко

Fig. 9. Mansi sanctuary - a house for spirits-patrons. Photo by S.A. Borisenko

щий отделом археологии палеометалла ИАЭТ СО РАН академик РАН В.И. Молодин рассказал на открытии выставки, что «история меча уходит в XI - начало XIII в. (судя по анализу надписи, последняя была выполнена в конце XII - начале XIII в.). Клинок меча был изготовлен в Центральной Европе, вероятно, где-то на территории Германии, в бассейне Рейна, а затем оказался в Швеции или на острове Готланд, где клинок снабдили богато украшенной серебром рукоятью». Кроме загадочного происхождения, для выставки интересен ритуальный характер меча, выраженный в сделанных на его клинке христианских посвятительных надписях.

Среди представленных предметов большую долю занимает вотивное оружие - то есть принесённое в качестве жертвы или подношения божествам с просьбой о здоровье, благополучии, «правильном» пути души в загробном мире. Вотивные предметы копировали настоящее вооружение, но делались зачастую меньшего размера. Традиция использования вотивного оружия универсальна для многих культур мира.

Культовая роль клинкового оружия в этнографии отражена в экспозиции сакральными предметами хантов, манси, эвенков, кетов и селькупов. На священных местах хантов и манси на Нижней Оби новосибирским этнографам часто встречались сабли, мечи и палаши, при этом как боевое оружие не использовались. Куратор выставки Аркадий Бауло рассказал, что оружие в регион стали привозить арабские купцы в XII-XIII вв., причём клинки часто были без эфеса 


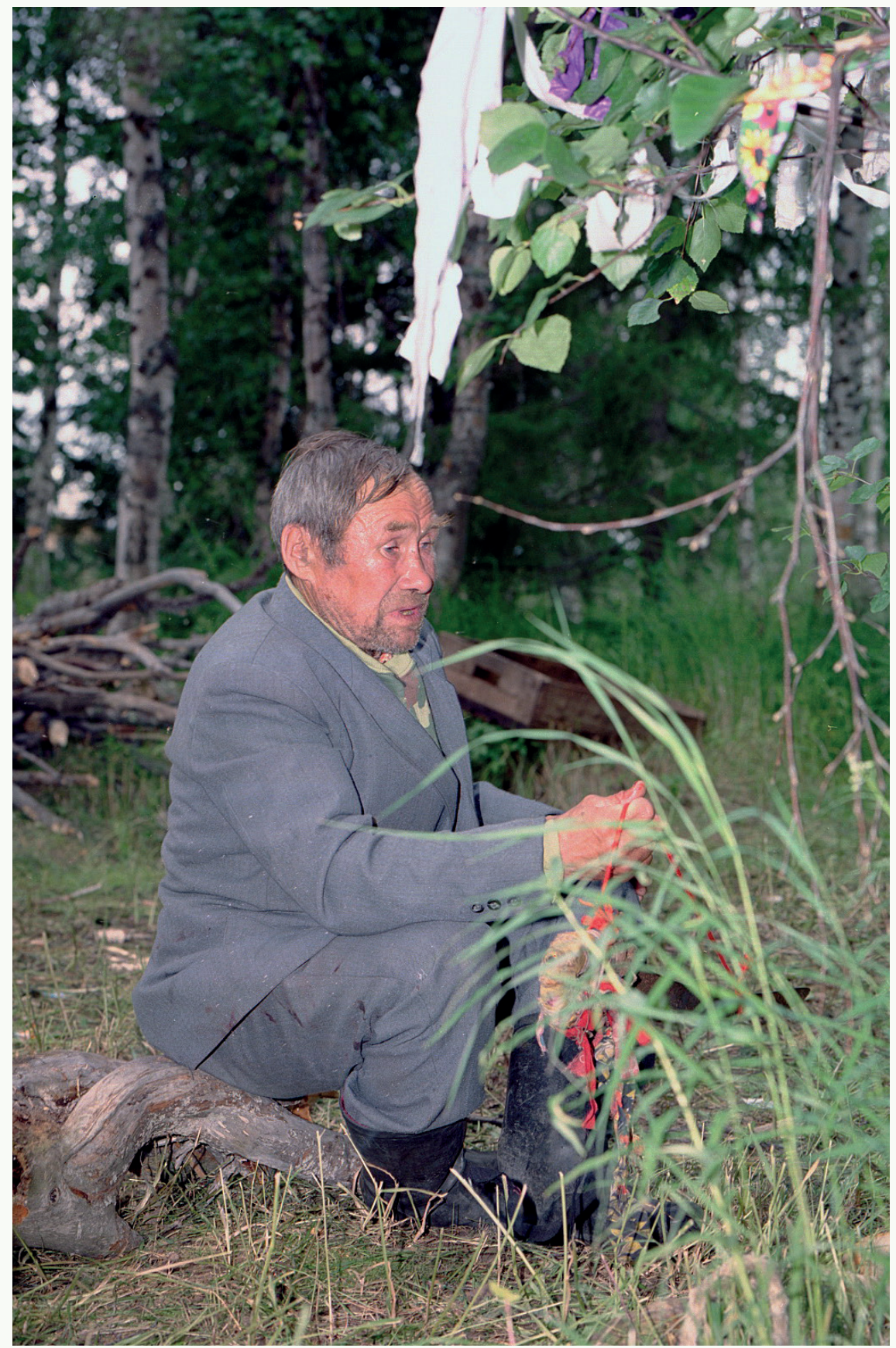

Puc. 10. Ворожба со шпагой. Фото из архива А.В. Бауло

Fig. 10. Fortune-telling with a sword. Photo from the A.V. Baulo's archive 


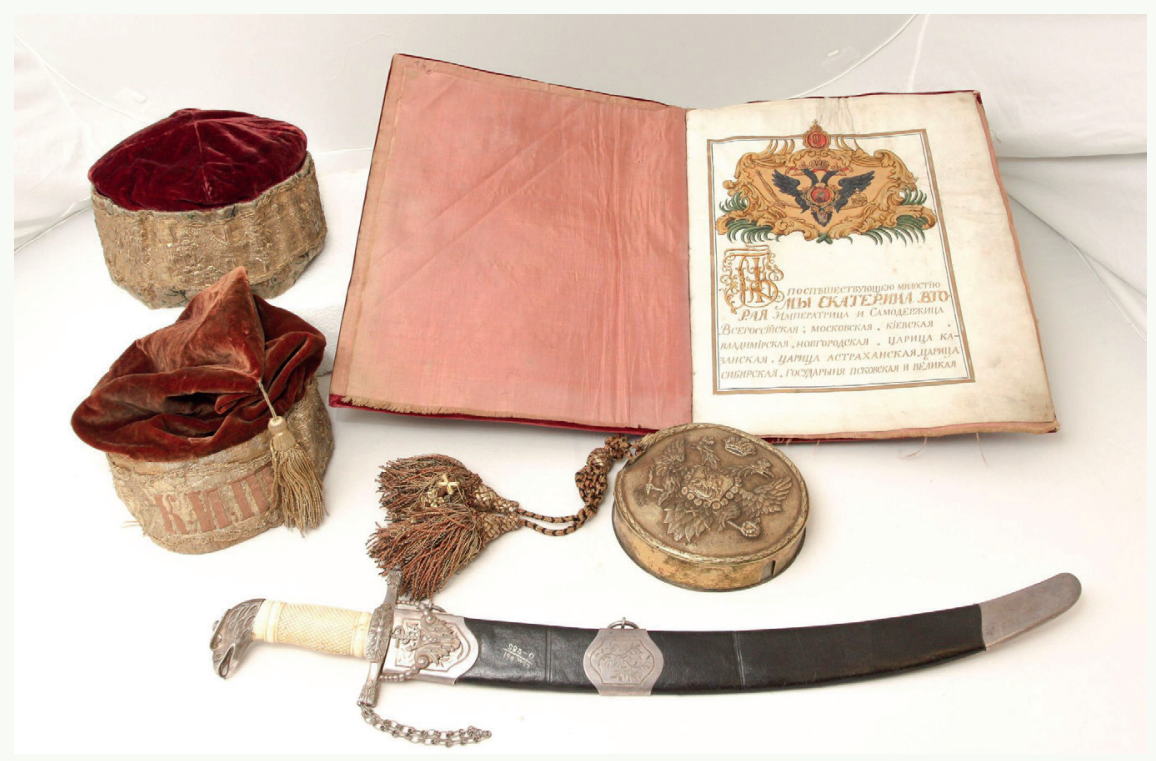

Puc. 11. Грамота на княжеское звание, жалованная Екатериной II владельцу Обдорской волости Матвею Тайшину, подаренные ему царицей кортик и шапки. Фото из архива Свердловского областного краеведческого музея

Fig. 11. The diploma for the princely rank, granted by Catherine the Second to Matvey Taishin, an owner of the Obdorsk Region. A dagger and hats - gifts of the Empress. Photo from the archive of the Sverdlovsk Regional Historical Museum

и без заточки - их предназначение было иным. Согласно традиционным представлениям хантов и манси, божественные предки этих народов были богатырями, и оружие было для таких богов лучшим даром.

Кроме того, само оружие могло считаться воплощением божества. В экспозиции представлена реконструкция мансийского лесного святилища, с амбарчиком для подношений и деревянными изваяниями - менквами, изображающими богов-предков (рис. 9). На ветку дерева у такого святилища подвешивали оформленную лоскутами ткани саблю и делали ей подношения как богу.

Наконец, шпага или сабля могли использоваться шаманами хантов и манси для гадания. А.В. Бауло так описывает этот обряд: шаман привязывал длинный шнур к кончику шпаги и к её эфесу, поднимал шпагу с помощью шнура на пальце и начинал раскачивать, напевая молитвы и обращая свои пожелания к божествам (рис. 10). Эвенские, кетские и селькупские шаманы во время плясок размахивали саблями, ритуально борясь со злыми духами или защищаясь от них. 


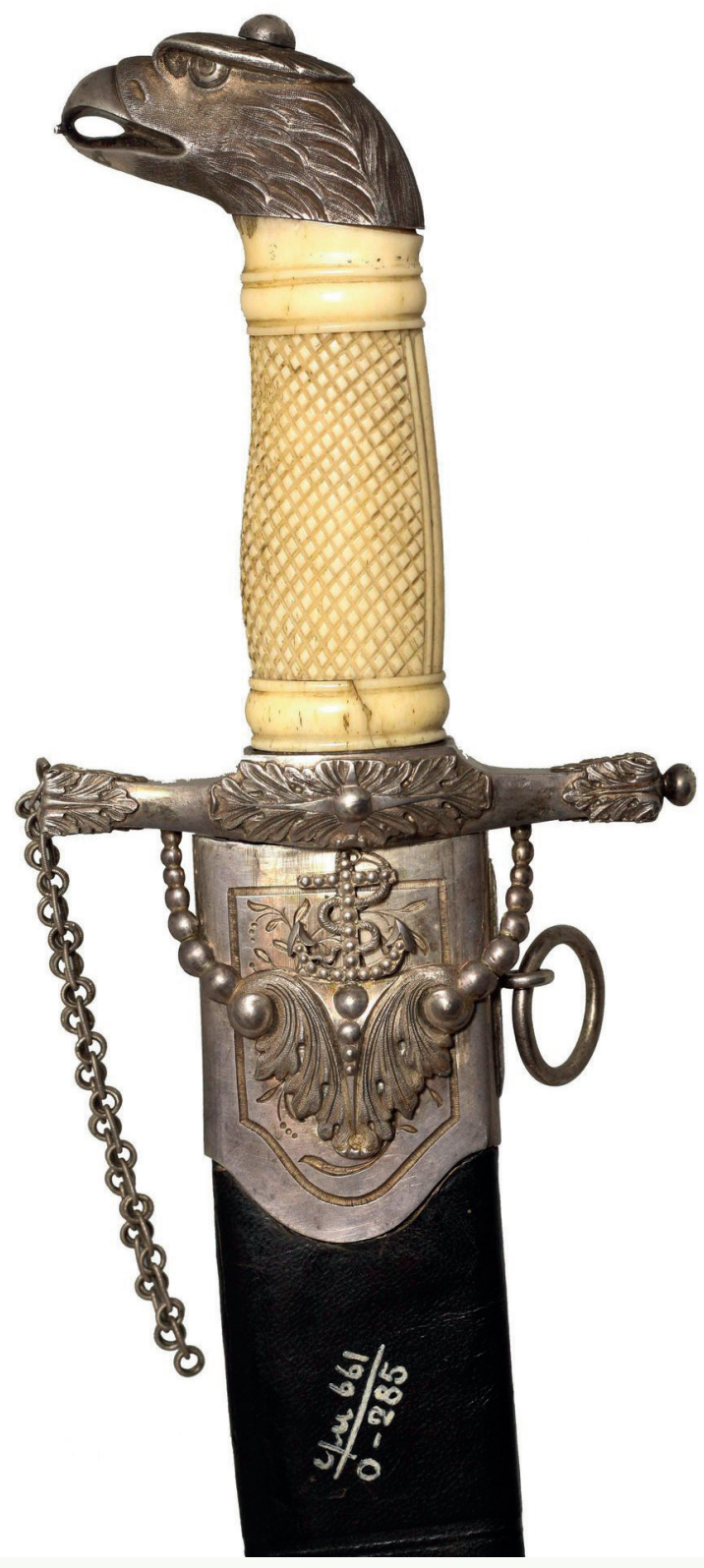

Puc. 12. Кортик, подаренный Екатериной II Обдорскому князцу Матвею Тайшину как знак его официальной власти.

Фото из архива Свердловского областного краеведческого музея

Fig. 12. The dagger presented by Catherine the Second to the Obdorsk prince Matvey Taishin as a symbol of his official power.

Photo from the archive of the Sverdlovsk Regional Historical Museum 

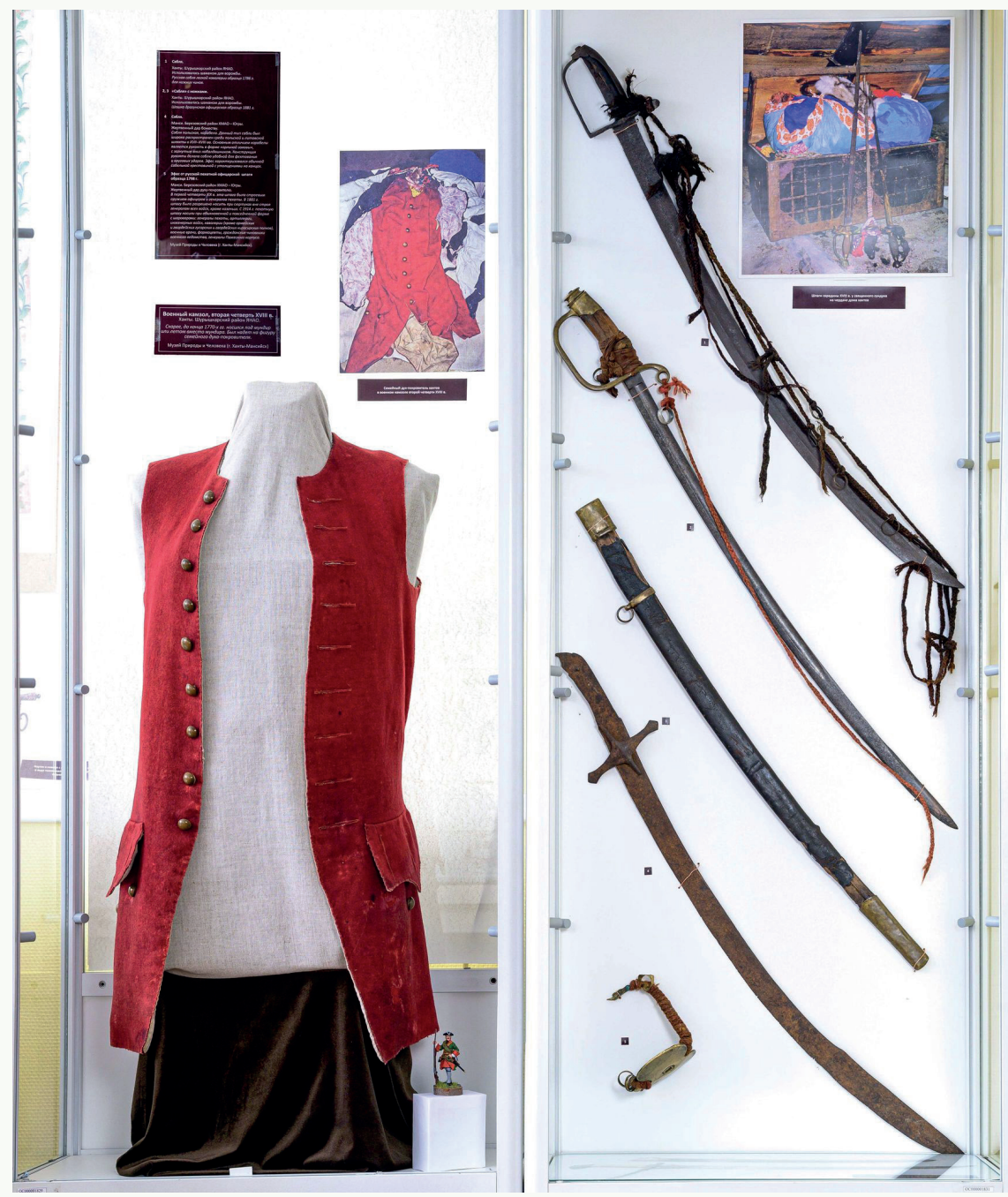

Puc. 13. Военный мундир, преподнесённый божеству. Фото С.А. Борисенко

Fig. 13. Military uniform presented to the deity. Photo by S.A. Borisenko

Русские, придя в Сибирь, встретили у коренных народов севера уже довольно крупные родоплеменные объединения. Русские стали называть их по своей традиции княжествами, а лидеров объединений - князьками. В экспозиции демонстрируется сюжет о поднесении Екатериной II князю Матвею Тайшину морского кортика в числе предметов, подтверждающих его властный статус с точки зрения российского государства (рис. 11-12). 




Puc. 14. Мундир чиновника, преподнесённый божеству. Фото С.А. Борисенко

Fig. 14. Official's tunic presented to the deity. Photo by S.A. Borisenko

Кроме оружия как символа власти или божественного статуса, выставка демонстрирует интересную традицию преподнесения богам русских военных мундиров (рис. 13). С ХІХ в. эта традиция несколько изменяется - вместо военного мундира преподносится мундир чиновника (рис. 14). Символическая фигура, олицетворяющая власть, меняется, но идея воплощения власти в специальной одежде и специальном вооружении сохраняется. 
В планах Института археологии и этнографии - демонстрация выставки осенью 2021 г. на новой площадке. Интересно будет наблюдать, какое развитие получит экспозиция!

\section{Сведения об авторе / About the author}

Гаркуша Дарья Дмитриевна, помощник директора по научнопросветительной работе, Институт археологии и этнографии СО РАН (пр-т Академика Лаврентьева, 17, Новосибирск, 630090, Россия)

Garkusha Daria Dmitrievna, assistant manager of the Head of the Institute of Archaeology and Ethnography of Siberian branch of the Russian Academy of Sciences (17, Academic Lavrentiev Av., Novosibirsk, 630090, Russia)

dar.garkusha@gmail.com

ORCID 0000-0002-8856-7495 